\title{
Particulate Matter Exposure of Passengers at Bus Stations: A Review
}

\author{
Le Thi Nhu Ngoc ${ }^{1}$, Minjeong Kim ${ }^{2}$, Vu Khac Hoang Bui ${ }^{1}$, Duckshin Park ${ }^{2, *}$ and \\ Young-Chul Lee ${ }^{1, * \mathbb{D}}$
}

1 Department of BioNano Technology, Gachon University, 1342 Seongnam-Daero, Sujeong-Gu, Seongnam-Si, Gyeonggi-do 13120, Korea; nhungocle92@gmail.com (L.T.N.N.); hoangvu210190@gmail.com (V.K.H.B.)

2 Korea Railroad Research Institute (KRRI), 176 Cheoldobakmulkwan-ro, Uiwang-si, Gyeonggi-do 16105, Korea; mjkim88@krri.re.kr

* Correspondence: dreamdbs@gachon.ac.kr (Y.-C.L.); dspark@krri.re.kr (D.P.); Tel: +82-31-750-8751 (Y.-C.L.); +82-10-3343-2862 (D.P.); Fax: +82-31-750-4748 (Y.-C.L.)

Received: 3 November 2018; Accepted: 14 December 2018; Published: 17 December 2018

\begin{abstract}
This review clarifies particulate matter (PM) pollution, including its levels, the factors affecting its distribution, and its health effects on passengers waiting at bus stations. The usual factors affecting the characteristics and composition of PM include industrial emissions and meteorological factors (temperature, humidity, wind speed, rain volume) as well as bus-station-related factors such as fuel combustion in vehicles, wear of vehicle components, cigarette smoking, and vehicle flow. Several studies have proven that bus stops can accumulate high PM levels, thereby elevating passengers' exposure to PM while waiting at bus stations, and leading to dire health outcomes such as cardiovascular disease (CVD), respiratory effects, and diabetes. In order to accurately predict PM pollution, an artificial neural network (ANN) and adaptive neuro-fuzzy inference systems (ANFIS) have been developed. ANN is a data modeling method of proven effectiveness in solving complex problems in the fields of alignment, prediction, and classification, while the ANFIS model has several advantages including non-requirement of a mathematical model, simulation of human thinking, and simple interpretation of results compared with other predictive methods.
\end{abstract}

Keywords: particulate matter; bus station; personal exposure; ANN model; ANFIS model

\section{Introduction}

Recently, particulate matter (PM) pollution has become an important concern worldwide due to its negative health effects. PM is small enough to penetrate and deposit into many organisms of the body. When exposed to PM for a long time, people may acquire serious symptoms related to cardiovascular diseases (CVD) (e.g., heartbeat, arrhythmia, and vascular dysfunction), lung cancer, skin irritation, diabetes, and especially respiratory health effects [1-5]. In particular, with population growth and the rise of private vehicles leading to increased levels of air pollution in the city center, people have been encouraged to travel by public transport such as the bus and subway system. However, it has been demonstrated that both the inside and outside of the bus and subway system accumulate high PM levels, and so passengers might be exposed directly to PM during their trips by public transport $[6,7]$.

Although the study of commuter exposure to air pollutants is not a new field of research, there has not been any focus on personal exposure assessments while passengers wait at bus stops. Several studies have identified the pollution at bus stations using various methods, and found that the $\mathrm{PM}_{10}$ and $\mathrm{PM}_{2.5}$ levels were too high compared with standard air quality guidelines in Europe, the Americas, and Asia [8-10]. For instance, $\mathrm{Xu}$ et al. (2015) determined that $\mathrm{PM}_{10}$ pollution is mainly attributed to diesel vehicle emissions (28\%), crustal dust (26\%), coal combustion $(22 \%)$, and cement $(4.9 \%)$ at bus 
stops in China. $\mathrm{PM}_{10}$ during rush hours $\left(254 \pm 128 \mu \mathrm{g} / \mathrm{m}^{3}\right)$ was 2.5 times higher than that during the ambient $24 \mathrm{~h}\left(103 \mu \mathrm{g} / \mathrm{m}^{3}\right)$ [6]. In a study by Moore et al. (2012), passengers waiting at bus stations in Portland, USA could be exposed to $\mathrm{PM}_{10}$ and $\mathrm{PM}_{2.5}$ at 25.00 and $21.97 \mu \mathrm{g} / \mathrm{m}^{3}$, respectively [7].

This present review provides an overview of PM pollution at bus station, focusing on the characteristics, health effects, and factors affecting PM as outlined in the following sections below: "Classification and sources of PM", "Health problems caused by PM exposure", and "Factors affecting PM pollution at bus stations", respectively. In addition, the personal exposure levels to pollutants around the world (Europe, the Americas, and Asia) are explicated in the section "Personal exposure to PM at bus stations". Next, in the section "Future directions for reduction in personal PM exposure", some PM-pollution predictive methods are proposed. Finally, a limitation and conclusions are given in the "Limitation of study" and "Conclusions" sections, respectively.

\section{Classification and Sources of PM}

PM is known as particle pollution, which contains micrometer-sized particles, including both inorganic and organic particles such as dust, soot, dirt, smoke, and liquid droplets [11-13]. Generally, PM originates from volcanoes, forest fires, dust storms, grassland fires, sea spray, and living vegetation. In addition, human activities including the burning of fossil fuels in traffic, industrial processes, and power plant operation also generate significant amounts of PM [11]. PM is composed of sulfur dioxide, elemental carbon known as black carbon, organic matter, and soot, all of which induce visual effects such as smog [11].

PM is classified based on its aerodynamic diameter, which is the main criterion for determining its ability to transport in air and penetrate the human body [14]. PM includes $\mathrm{PM}_{10}$, with an aerodynamic diameter $10 \mu \mathrm{m}$ or less; fine aerodynamic particulate is defined as $\mathrm{PM}_{2.5}$ of $2.5 \mu \mathrm{m}$ or less in diameter, and ultrafine particles $\left(\mathrm{PM}_{0.1}\right)$ are categorized as extremely small, less than $0.1 \mu \mathrm{m}$ in diameter $[11,12,15]$. The sizes of $\mathrm{PM}_{10}$ and $\mathrm{PM}_{2.5}$ can be compared to the diameters of fine beach sand $(\sim 90 \mu \mathrm{m})$ and human hair $(\sim 70 \mu \mathrm{m})$, respectively (Figure 1). $\mathrm{PM}_{10}$ (coarse PM) is known as inhalable particles that can penetrate into the respiratory tract (e.g., trachea, deep lungs, and bronchi) $[14,16,17]$. The coarse fraction of $\mathrm{PM}_{10}$ generally originates from construction and demolition operations, paved and unpaved roads, industrial processes, and agriculture as well as biomass burning $[14,18]$. On the other hand, $\mathrm{PM}_{2.5}$ can be emitted directly from the combustion of vehicles, industry, smokestacks, fires, and via atmospheric reactions of gases (e.g., $\mathrm{NO}_{x}$ and $\mathrm{SO}_{2}$ ) [12,14,18], $\mathrm{PM}_{2.5}$ can easily enter the alveolar region of the lung $[16,17,19,20]$. At bus stations, $\mathrm{PM}_{2.5}$ is particularly problematic, because waiting passengers can be easily exposed to this particulate as generated by the fuel burning process in vehicles (e.g., motorcycles, trucks cars, buses, and heavy-duty vehicles). [16]. According to a report of the World Health Organization (WHO) (2003) on PM in Europe, the annual average mass concentrations of both $\mathrm{PM}_{10}$ and $\mathrm{PM}_{2.5}$ are mainly contributed by sulfates, organic matter, nitrate, and black carbon [13].

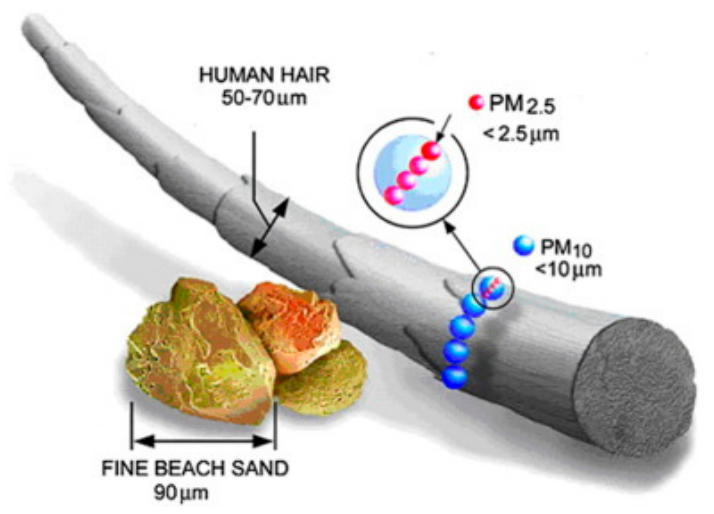

Figure 1. Size comparisons of particulate matter (PM) [12]. "Reproduced with permission from (Kim et al., Environment International) published by (Elsevier, 2015)". 
Recent studies indicate that traffic, specifically wear and tear of vehicle components (e.g., tires and brakes) and road dust suspension, is one of the major sources of PM [19,21]. Indeed, in the big cities around the world, increased demand for transportation in the forms of cars, buses, and subways, has led to increased air pollution from vehicle emissions [22]. The Department of Transport in the United Kingdom (UK) reported a 21\% increase in vehicle traffic from 2000 to 2010 (Figure 2) [22]. The wide variety of pollutants and PM emitted from these sources is primarily composed of volatile organic compounds (VOCs), nitrogen oxides $\left(\mathrm{NO}_{\mathrm{x}}\right)$, sulfur dioxide $\left(\mathrm{SO}_{2}\right)$, carbon monoxide $(\mathrm{CO})$, carbon dioxide $\left(\mathrm{CO}_{2}\right)$, and metal particles [21-23].

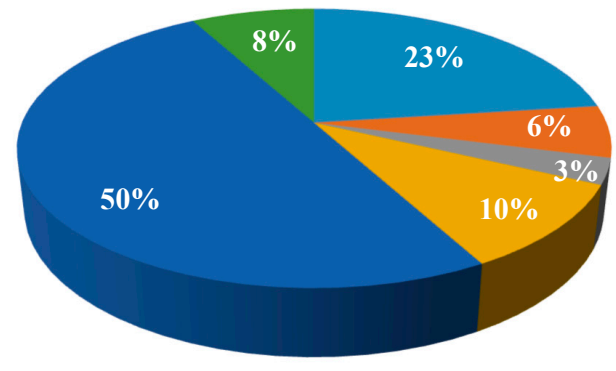

\author{
- Power Stations \\ Dosmetic and Commercial \\ - Refineries, Iron, and Stell \\ Other Industry \\ - Transport \\ - Other
}

Figure 2. Sources of $\mathrm{PM}_{10}$ (coarse PM) pollution in UK (2001) [22].

Particularly, buses have been considered as an environmentally friendly form of transport relative to cars and other types. Buses utilize less fuel per person carried, thus producing less pollution than the number of either cars or motorbikes replaced [22,24]. Nevertheless, diesel engines used in buses emit large amounts of $\mathrm{NO}_{\mathrm{x}}$, leading to larger emissions of black smoke and PM. Black smoke consists of numerous PM responsible for the soiling of buildings, and $\mathrm{PM}_{2.5}$ is correlated with a variety of adverse health effects [25].

\title{
3. Health Problems Caused by PM Exposure
}

The exposure effectiveness of PM depends not only on its chemical compositions and physical properties that can be influenced by local conditions including weather, seasons, sources of particles, and concentrations emitted [26], but also on human physical characteristics (e.g., breathing mode and volume of a typical person). Particle size is primarily responsible for the association between PM and human health problems: smaller particles can more easily penetrate into the human body and deposit deep into the respiratory tract $[19,27]$. Indeed, Atkinson et al. indicated that the cilia and mucus in nasal-breathing effectively filter only most particles greater than $10 \mu \mathrm{m}$ in diameter; thus, $\mathrm{PM}_{10}$ and $\mathrm{PM}_{2.5}$ can easily infiltrate the body, settle down rapidly, and lodge in the bronchi or trachea (upper throat). However, the body may react to eliminate these intrusive PM via processes such as sneezing and coughing [28]. Londahl et al. acknowledged that particles less than $10 \mu \mathrm{m}$ in diameter can enter the respiratory tract, starting from the nasal passages and proceeding into the alveoli and deep within the lungs, due to their excessive penetrability [29]. In addition, whereas particles in the range of 5-10 $\mu \mathrm{m}$ are most likely to be deposited in the tracheobronchial tree, those from 1 to $5 \mu \mathrm{m}$ tend to be deposited in the alveoli and the respiratory bronchioles where gas exchange occurs [29,30] (Figure 3). During deposition in the lung, these particles may interfere with gas exchange and then escape into the bloodstream, resulting in significant health problems $[19,30]$. On the other hand, particles smaller than $1 \mu \mathrm{m}$ behave like gas molecules, thus entering into the alveoli (deposited by diffusion forces), and move further into tissue and the circulatory system [31]. Generally, as the human body cannot prevent exposure or adversely effects by PM, people may experience several health problems including CVD, respiratory health effects, diabetes, and premature death [1,23]. The WHO (2016) estimates that PM pollution contributes to about 4.2 million premature deaths each year $(16 \%$ of lung cancer deaths, $26 \%$ of respiratory infection deaths, $17 \%$ of ischemic heart disease and stroke deaths, and $25 \%$ of chronic obstructive pulmonary disease deaths), ranking it as the 14th leading cause of death worldwide [32-34]. 


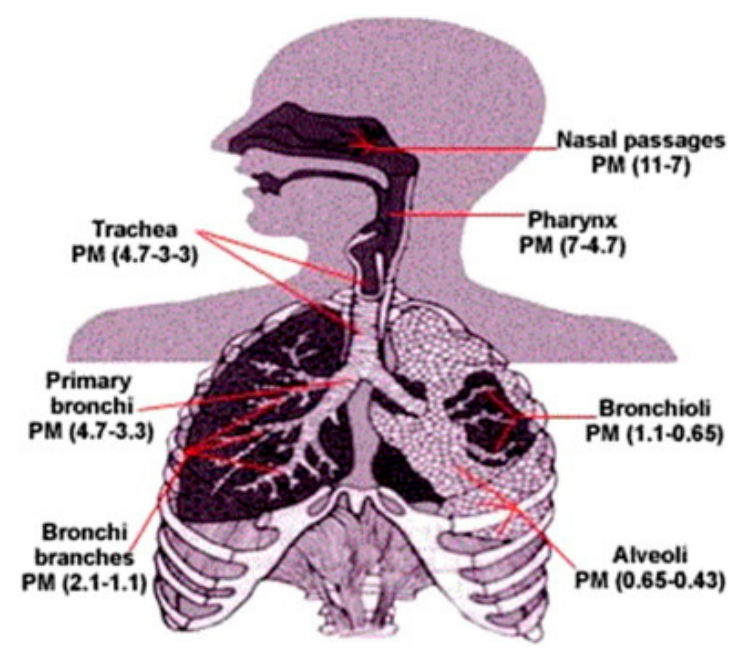

Figure 3. Potential for deposition of particles of different sizes [19]. "Reproduced with permission from Kim et al. (Environment International; published by Elsevier, 2015)".

\subsection{Cardiovascular Diseases (CVD)}

Cardiovascular diseases (CVD) are recognized as some of the leading causes of mortality and morbidity in the world [35,36]. Recently, many traditional CVD risk factors have been identified, such as high blood pressure, diabetes, physical inactivity, smoking, and especially air pollution $[1,19,37]$. Particularly, PM is an important CVD risk factor in cases where people are exposed over long durations, because it can easily penetrate and deposit deep into the organism through several pathways both direct and indirect (Figure 4) [1,2,38]. Via the direct pathway, these particles translocate into the bloodstream and remote specific target organs [38,39]. In this systemic circulation, reactive oxygen species and ion channel interference play an important role in affecting the heart and vasculature [40]. In contrast, indirectly, these particles induce pulmonary-mediated oxidative stress and inflammatory responses, resulting in a less acute and adverse effects after several hours and days of inhalation [38-42].

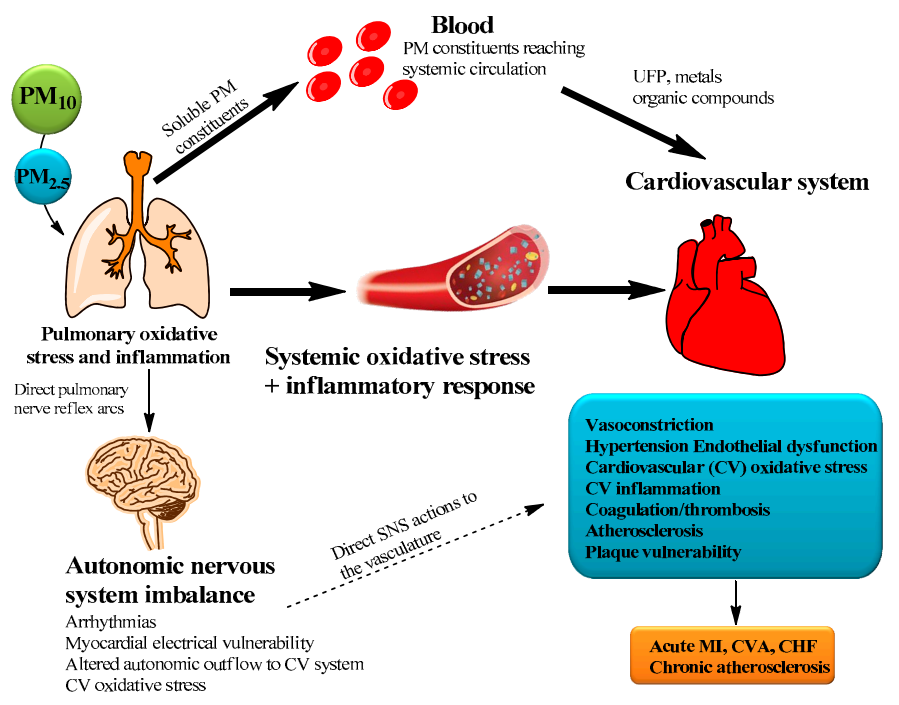

Figure 4. Biological pathways which PM can cause cardiovascular disease (CVD) [43]. (UFP: Ultrafine particle, MI: Myocardial infraction, CVA: Cerebrovascular accident, and CHF: Congestive heart failure).

\subsubsection{Effects of Short-Term Exposure}

Several studies have estimated that short-term PM exposure ( $\sim$ a few days) and PM increase of $10 \mu \mathrm{g} / \mathrm{m}^{3}$ are associated with increased relative risk (RR) of daily CVD mortality in both $\mathrm{PM}_{10}$ and $\mathrm{PM}_{2.5}$ of $0.6-1.8 \%$ and $0.6-1.3 \%$, respectively [32,39]. In addition, these PM concentrations may 
present a major acute risk for elderly people and those with heart diseases [44]. Although the risk to an individual at any one time point may be small, the burden on public health is enormous. An increase in short-term PM exposure leads to tens of thousands of mortalities per year in the United States. According to the Nation Morbidity Mortality Air Pollution Study (NMMAPS) data, an increase of $10 \mu \mathrm{g} / \mathrm{m}^{3}$ in $\mathrm{PM}_{10}$ caused a $0.7 \%$ increase in cardiopulmonary mortality (95\% confidence interval (CI), $0.2-1.2 \%$ ) [45]. In another study on the 38 biggest of China's cities by Yin et al., the effect of increase per $10 \mu \mathrm{g} / \mathrm{m}^{3} \mathrm{PM}_{10}$ on deaths from cardiorespiratory diseases was $0.62 \%$ (95\% CI $0.43-0.81 \%$ ), compared with $0.26 \%(95 \%$ CI $0.09-0.42 \%)$ for other causes of mortality [46]. In another, smaller trial on 12,000 patients in Utah, Pope et al. determined that a $10 \mu \mathrm{g} / \mathrm{m}^{3}$ increase in $\mathrm{PM}_{2.5}$ resulted in a $4.5 \%(95 \% \mathrm{CI}$, $1.1-8.0 \%)$ increase in acute ischemic coronary events [44].

\subsubsection{Effects of Long-Term Exposure}

The adverse effect of long-term exposure to PM has been identified as even more harmful than short-term exposure in the "Harvard Six Cities" study, which showed that living in the heaviest polluted cities increased the risk of CVD mortality by 30\% [39]. In 2007, a women's health initiative study estimated that long-term PM exposure leads to a $24 \%\left(95 \%\right.$ CI, 9-41\%) increase in CVD per $\mathrm{PM}_{2.5}$ increase of $10 \mu \mathrm{g} / \mathrm{m}^{3}$ [47]. In addition, PM pollution is associated with CVD morbidity, as observed by some studies focused on hospital admissions for CVD. According to the Medicare data for 204 U.S. cities, a rise of $10 \mu \mathrm{g} / \mathrm{m}^{3}$ in $\mathrm{PM}_{2.5}$ concentration results in increased hospitalization for cerebrovascular disease $(+0.81 \%)$, ischemic heart disease $(+0.44 \%)$, arrhythmias $(+0.57 \%)$, peripheral arterial disease $(+0.86 \%)$, and heart failure $(+1.28 \%)[39,48,49]$.

\subsection{Respiratory Effects}

Exposure to PM has been proven to be associated with a variety of respiratory health effects including respiratory symptoms (cough, phlegm, and wheeze), bronchial hyper-reactivity, acute-phase reaction, respiratory infections, decreased lung growth in children, chronic loss of pulmonary function in adults, and premature mortality in patients with chronic lung disease [1,50]. PM's respiratory mechanisms consist of pulmonary injury from free radical peroxidation, imbalanced intracellular calcium homeostasis, and inflammation injury (Figure 5) [1,4,5,32]. In fact, when it enters the body, PM can directly affect macrophages, in which the alveolus responds rapidly to inhaled PM as an initial innate immune response, and then produces nitrogen species, reactive oxygen species, and releases TNF- $\alpha$ and IL-1, thus resulting in epithelial cell apoptosis and inflammation [32,51,52]. Besides, induced mitochondrial fusion and mitochondrial lipid peroxidation in lung macrophages might be an important mechanism contributing to respiratory diseases caused by PM [52].

According to the report of the $\mathrm{WHO}$, approximately $16 \%$ of lung cancer deaths, $11 \%$ of chronic obstructive pulmonary disease (COPD) deaths, and 13\% of respiratory infection deaths are caused by exposure to air pollution [52]. In addition, an American Cancer Society cohort study of 1.2 million American adults for 26 years (from 1982-2008) showed that with a $\mathrm{PM}_{2.5}$ increase of $10 \mu \mathrm{g} / \mathrm{m}^{3}$ per day, lung cancer mortality increased by $15-27 \%$ [4]. In another study, Karakatsani et al. reported that a $10 \mu \mathrm{g} / \mathrm{m}^{3}$ increase the in previous-day $\mathrm{PM}_{10}$ concentration was positively correlated with a $1.06 \%$ increase in cough symptoms (95\% CI: 1.01-1.11) [53]. Guo et al. (2018) determined that long-term exposure to $\mathrm{PM}_{2.5}$ was linked to reduction and faster decline of lung function and that it was also associated with a significant increase in COPD risk (1.39\%; 95\% CI, 1.24-1.56) in Taiwan [54]. Jo et al. evaluated the effect of PM on patients at a hospital in South Korea (between 2007 and 2010) in terms of respiratory diseases. At that time, for the mean daily $\mathrm{PM}_{10}$ and $\mathrm{PM}_{2.5}$ concentration of $49.6 \pm 20.5$ and $24.2 \pm 10.9 \mathrm{mg} / \mathrm{m}^{3}$, the mean numbers of acute bronchitis, allergic rhinitis, and asthma cases were $5.8 \pm 11.9,4.4 \pm 6.1$, and $3.3 \pm 3.3$, respectively [55]. 


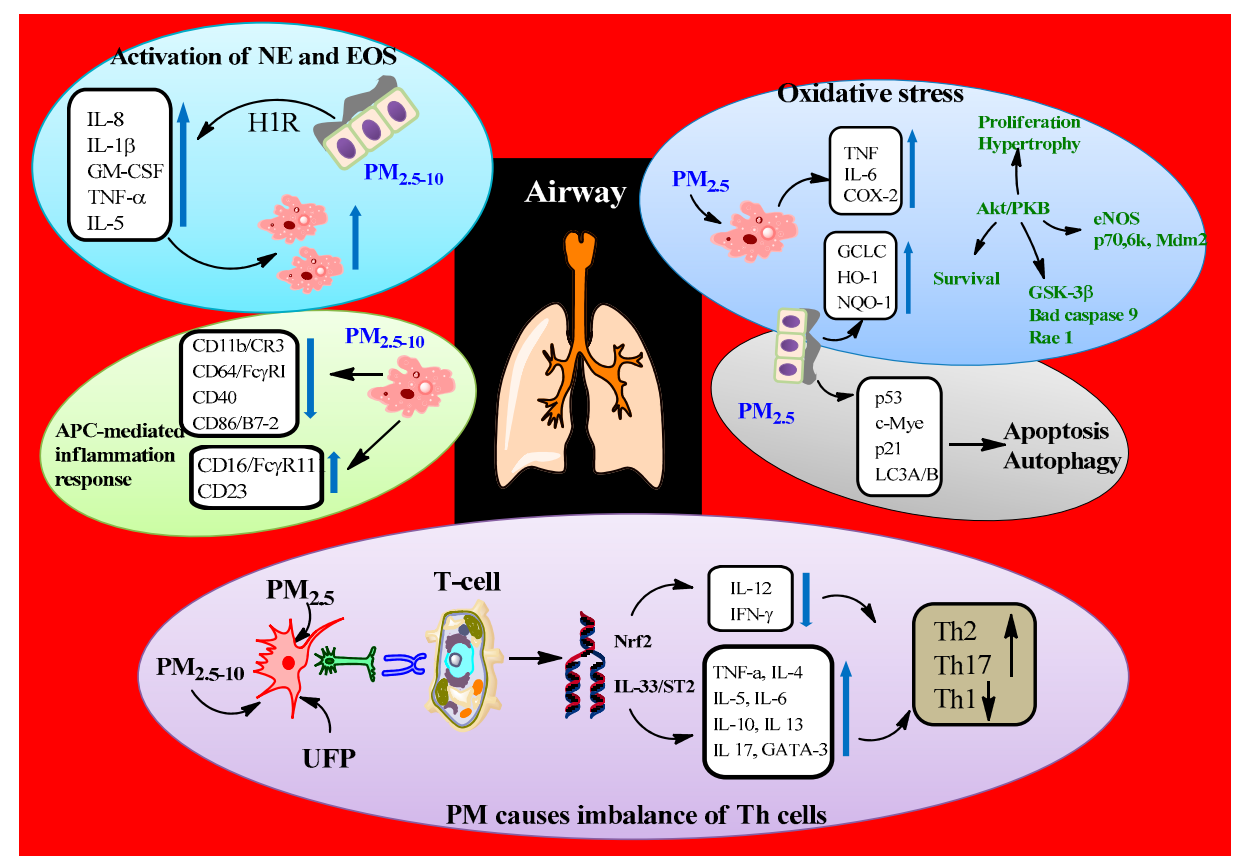

Figure 5. Mechanisms of PM's effect in allergic respiratory diseases [51].

\subsection{Diabetes}

Recently, at least five publications have identified the relationship between air pollution, especially PM, and diabetes [56-60], and showed that the main mechanism of PM's increased incidence of diabetes is significantly involved in endothelial and mitochondrial dysfunction and inflammation of visceral adipose tissues [3]. In particular, the long-term exposure of adipose tissue macrophages to PM was characterized by increased IL- 6 and TNF- $\alpha$ as well as reduced expression of IL-10, thereby promoting the production of innate immune cells in adipose tissue, which is pathophysiologic of type 2 diabetes $[3,61]$. In addition, this prolonged exposure also reduces inter-scapular brown adipose tissue (BAT) and mitochondrial size, which effects are accompanied by increases in nitrosative and oxidative stress in BAT, in combination with antioxidant gene induction including nicotinamide adenine dinucleotide phosphate (NADPH) quinone oxidoreductase 1, NF-E2-related factor 2, and glutamate-cysteine ligase modifier subunit, resulting in the downregulation of insulin in adipose gene profiles and reduction of uncoupling protein expression, all of which are risk factors for development of type 2 diabetes [62].

In fact, He et al. reported that $\mathrm{PM}_{2.5}$ was $1.25 \%$ positively correlated with incidence of type 2 diabetes mellitus over a long-term exposure period (95\% CI, 1.10-1.43). Therefore, with a $10 \mu \mathrm{g} / \mathrm{m}^{3}$ increase in $\mathrm{PM}_{2.5}$ per day, the incidence of type 2 diabetes would increase by 25\% [63]. In a systematic review by Liang et al. (2014), $\mathrm{PM}_{2.5}$ was closely related to blood pressure variation of $1.39 \mathrm{mmHg}$ (95\% CI, 0.87-1.91) per $10 \mu \mathrm{g} / \mathrm{m}^{3}$ increase in $\mathrm{PM}_{2.5}$ [57]. In addition, in another study, Hansen et al. (2016) found that $\mathrm{PM}_{10}$ and $\mathrm{PM}_{2.5}$ were potential risk factors for diabetes development. The incidence of diabetes increased by $1.06 \%$ (95\% CI, 0.98-1.14) and $1.11 \%$ (95\% CI, 1.02-1.22) for each increase of $2.8 \mu \mathrm{g} / \mathrm{m}^{3}$ in $\mathrm{PM}_{10}$ and $3.1 \mu \mathrm{g} / \mathrm{m}^{3}$ in $\mathrm{PM}_{2.5}$, respectively [56].

\section{Factors Affecting PM Pollution at Bus Stations}

\subsection{Meteorological Factors}

Several environmental factors have been identified during $\mathrm{PM}_{10}$ and $\mathrm{PM}_{2.5}$ monitoring at bus stations. The association between PM, airborne particles, and meteorological parameters (e.g., wind speed, temperature, relative humidity, pressure, rain volume, and cloudiness) have been investigated in several recent studies [64-69]. 
Akyuz et al. studied the meteorological dependence of PM concentrations in winter and summer periods according to Pearson's correlation analysis in Zonguldak, Turkey [65]. There were significant differences in the seasonal variations of $\mathrm{PM}_{10}$ and $\mathrm{PM}_{2.5}$ concentrations. In particular, the maximum daily $\mathrm{PM}_{10}$ and $\mathrm{PM}_{2.5}$ concentrations reached $66.7 \mu \mathrm{g} / \mathrm{m}^{3}$ and $32.4 \mu \mathrm{g} / \mathrm{m}^{3}$ in summer, and $116.7 \mu \mathrm{g} / \mathrm{m}^{3}$ and $83.3 \mu \mathrm{g} / \mathrm{m}^{3}$ in winter, respectively. The authors pointed out that atmospheric pressure indirectly influences pollutant concentrations by affecting atmospheric stability conditions. Indeed, high atmospheric pressure leads to low wind speed and stable stratification, which limit the spread of pollutants within the atmosphere [65].

Tecer et al. indicated that temperature has a significant negative effect on PM concentration with respect to the occurrence of episodic events in Turkey. The concentrations of $\mathrm{PM}_{10}$ and $\mathrm{PM}_{2.5}$ increased 7 and 6 times at the lowest temperature $\left(10^{\circ} \mathrm{C}\right)$, respectively [64]. They also reported that the wind speed increased from 1.39 to $2.80 \mathrm{~m} / \mathrm{s}$, resulting in an increase in pollution levels per day. Besides, when wind speed is too high, PM can be transported from nearby sources by the dilution effects of the wind, which indeed plays an important role in PM movements [64].

In another study, this one by Unal et al., variations of $\mathrm{PM}_{10}$ concentrations as influenced by meteorological factors including wind direction, wind speed, and high pressure in Istanbul were analyzed [68]. Figure 6 showed that with increases of wind speed, the average concentration of $\mathrm{PM}_{10}$ was higher than $50 \mu \mathrm{g} / \mathrm{m}^{3}$ and typically highest with winds blowing in the south-west (SW) and east-north-east (ENE) directions. They also demonstrated that a high pressure system can induce light wind and stable atmospheric conditions, in consequence of which, the highest $\mathrm{PM}_{10}$ level was found, and vice versa for strong wind and unstable atmospheric conditions [68].

Fondelli et al. studied $\mathrm{PM}_{2.5}$ concentrations during working days and in heavy traffic to predict ambient pollution levels in Florence, Italy [67]. According to data from the Tuscan Environmental Protection Agency (ARPAT) for 24-h $\mathrm{PM}_{2.5}$ measurements, they analyzed and estimated that $\mathrm{PM}_{2.5}$ hourly averages were closely correlated with pressure, precipitation, wind speed, and wind direction. In this study, low wind speeds (average below $2 \mathrm{~m} \cdot \mathrm{s}^{-1}$ ) effected increases in $\mathrm{PM}_{2.5}$ mass and composition [67].

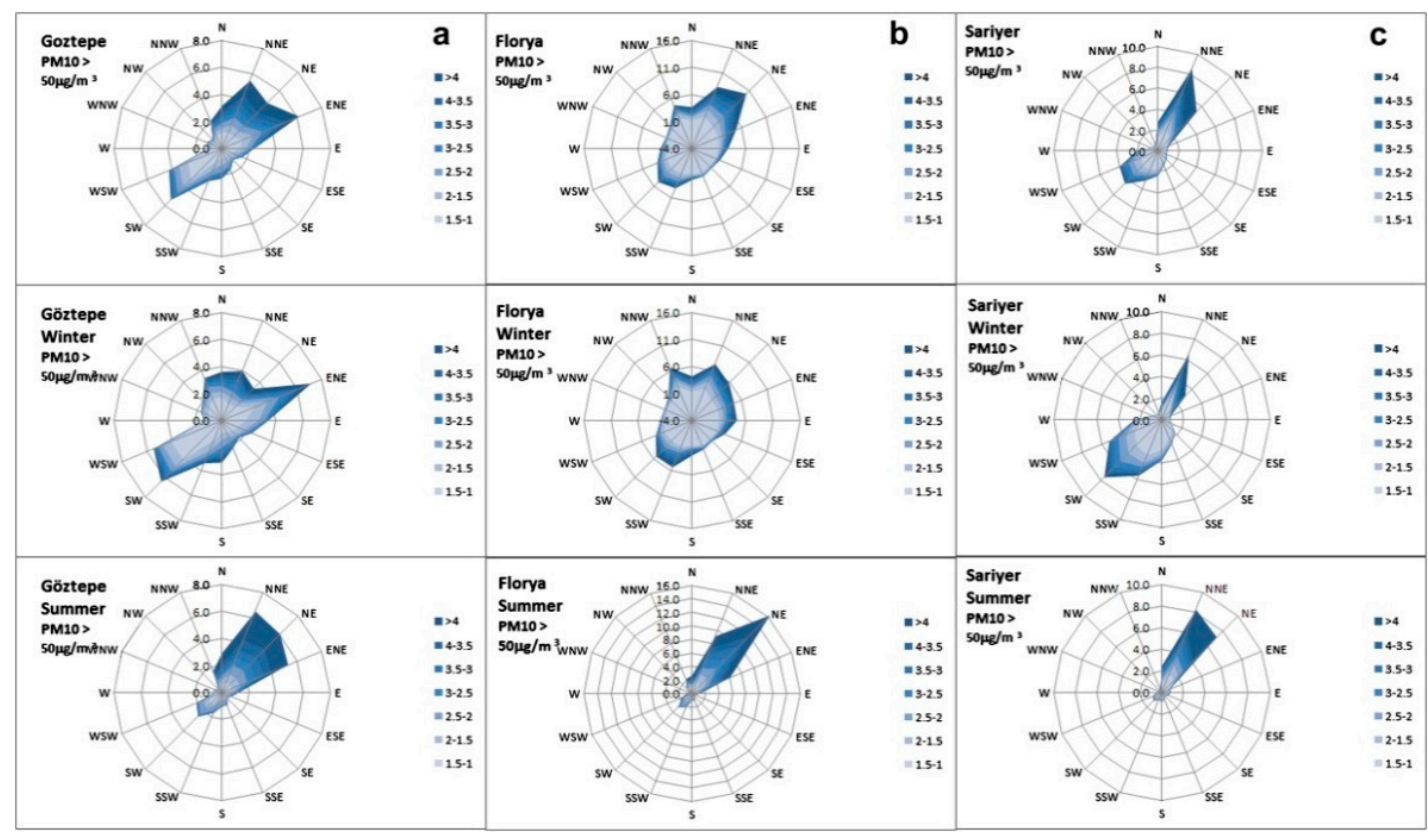

Figure 6. Wind speed increases annually in winter and summer seasons for (a) Goztepe, (b) Florya, and (c) Sariyer in Istanbul and their effects on classified $\mathrm{PM}_{10}$ levels [68]. "Reproduced with permission from Unal et al., (Atmospheric Environment; published by Elsevier, 2011)". 


\subsection{Traffic Factors}

Among the environmental factors influencing PM concentrations, traffic is the major one at bus stations [10,66,70]. According to the report of the Air Quality Expert Group (AQEG) (2012) in the UK, road traffic contributes significantly to the existence of $\mathrm{PM}_{2.5}$ in ambient air pollution [71]. Indeed, traffic is closely associated with $\mathrm{PM}_{2.5}$ pollution via two pathways including exhaust particles produced from gasoline- and diesel-engine vehicles (e.g., buses, private vehicles, and motorcycles) and non-exhaust particles originating from various physical processes (e.g., tire and brake wear, tire abrasion of road surface, and blowing off of dust particles caused by vehicle motion) [10].

Moreover, the internal fossil fuel combustion of diesel buses is known to be the main mobile source of PM emissions at bus stations. Bus types, traffic volume, and the presence of cigarette smoking at bus shelters also are factors [66]. In addition, the location of bus shelters is one of the contributors to personal exposure to PM. Most bus shelters are usually located on main roads or near intersections; thus, particles originally exhausted from other private vehicles will easily accumulate, especially during rush hours or green lights near bus stops, when vehicle flows are high $[10,66]$. Consequently, passengers waiting at bus shelters can be exposed directly to large amounts of PM. Moreover, Hess et al. (2010) evaluated the role of individual cigarette smoking on PM pollution at bus stations, finding that the presence of cigarette smoking at the level of 0.01 increased the $\mathrm{PM}_{2.5}$ exposure of waiting passengers by $22.74 \mu \mathrm{g} / \mathrm{m}^{3}$ [66].

The effects of traffic factors on PM concentration have been determined by various methods. Zhang and Batterman (2010) used generalized additive models to estimate vehicle contributions to PM pollution near roadways [72]. They indicated that traffic count was in a positive relationship with $\mathrm{PM}_{2.5}$ concentration rise at points near the road (Figure 7).
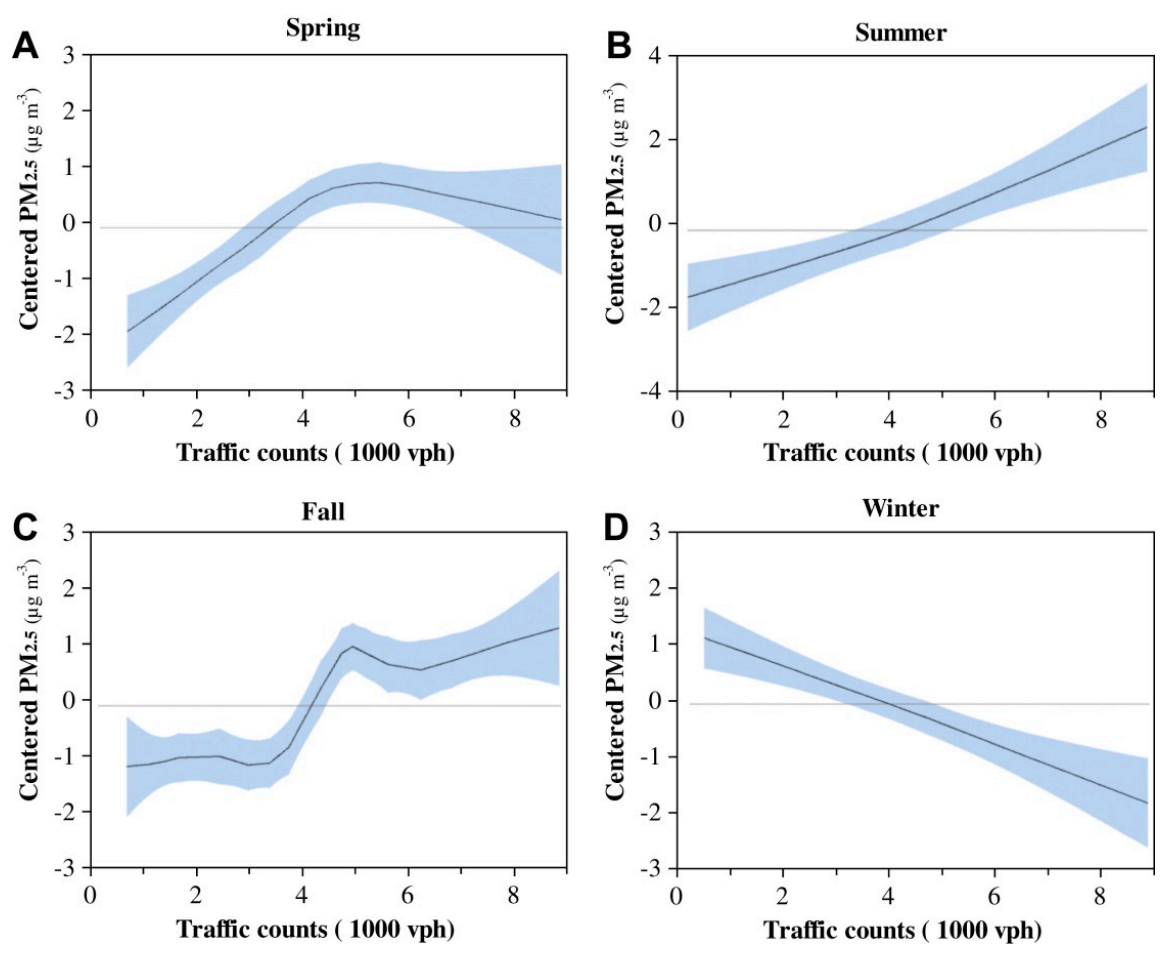

Figure 7. Relationship between $\mathrm{PM}_{2.5}$ concentrations and general traffic counts at major highway in Detroit, Michigan during summer season [10,72]. "Reproduced with permission from (Zhang and Batterman, Atmospheric Environment; published by Elsevier, 2010)".

In addition, PM pollution is also correlated with vehicle flow [21,73]. In an investigation by Moore et al. (2012), averages of 1267 and 1415 vehicles per hour at bus shelters in the morning and evening, respectively, were positively associated with $\mathrm{PM}_{10}$ and $\mathrm{PM}_{2.5}$ pollution in Powell Boulevard, 
UK. Besides, the authors pointed out that the orientation of bus shelters also influenced the distribution of PM inside and outside. They observed that there were higher PM concentrations inside than outside of shelters oriented toward the roadway. Contrastingly, the concentrations were higher outside than inside of shelters oriented away from the roadway [73].

\section{Personal Exposure to PM at Bus Stations}

\subsection{PM Exposure Levels in Europe}

In the 1999-2000 period, due to excessive levels of PM in London, UK, Adams et al. conducted a comprehensive $\mathrm{PM}_{2.5}$ personal exposure study of users of bus, car, and bicycle transport [74]. It was estimated that passengers during bus transit and while waiting at bus stops were exposed to $34.0 \pm 1.8 \mu \mathrm{g} / \mathrm{m}^{3}$ and $30.9 \pm 2.1 \mu \mathrm{g} / \mathrm{m}^{3}$ in the summer and winter, respectively. They also indicated that meteorological variables, traffic density, and route are all closely linked to individual exposure. Wind speed was found to be the most important factor influencing personal exposure, higher wind speeds leading to lower personal exposure levels. In particular, the difference in personal exposure was 1.5-2.0 times when comparing the 10th and 90th percentiles of wind speeds. In 2009, Kaur et al. calculated personal exposures to $\mathrm{PM}_{2.5}$ in Central London, UK by five transport models (walking, car, taxi, cycling, and bus) [75]. The analyses estimated that for an average temperature of $14{ }^{\circ} \mathrm{C}$, $70 \%$ humidity, and a wind speed of 1 to $5.8 \mathrm{~m} /$ second, $\mathrm{PM}_{2.5}$ concentrations were obtained at an average of $34.1 \pm 11.3 \mu \mathrm{g} / \mathrm{m}^{3}$ during waiting and transit by bus. In another study, Cevallos monitored $\mathrm{PM}_{2.5}$ pollution at seven bus stops on the campus of the University of Manchester, UK, and found that the concentration of pollutant was obtained in the range of $13.66-25.72 \mu \mathrm{g} / \mathrm{m}^{3}$ [10]. In addition, they reported that bus stop direction and design were correlated with local exhaust emissions and meteorological factors contributing to differences in PM levels inside and outside of bus stations [10].

Onat and Stakeeva (2013) assessed the personal exposure of commuters in public transport to $\mathrm{PM}_{2.5}$ in central Istanbul, Turkey. The highest average $\mathrm{PM}_{2.5}$ exposure of bus passengers was $120.4 \pm 73.5 \mu \mathrm{g} / \mathrm{m}^{3}$ and $84.5 \pm 42.8 \mu \mathrm{g} / \mathrm{m}^{3}$ during rush hours and non-rush hours, respectively [20]. Further, they evaluated wind speed, temperature, and relative humidity affecting $\mathrm{PM}_{2.5}$ concentration distribution. The $\mathrm{PM}_{2.5}$ concentration was positively associated with humidity and wind speed ( 0.70 for inside bus and bus shelter), and negatively correlated with temperature (temperature increased as particle concentration decreased).

Fondelli et al. (2008) evaluated urban fine particle exposure concentrations inside and outside of bus stations in Florence, Italy [67]. At fixed-site monitoring stations, the average $\mathrm{PM}_{2.5}$ concentration was $32 \mu \mathrm{g} / \mathrm{m}^{3}$ (in the range of $22-52 \mu \mathrm{g} / \mathrm{m}^{3}$ ). According to the report of time-microenvironmentactivity-diary data, the average exposure of Florentines was about $12 \%$ of personal $\mathrm{PM}_{2.5}$ exposure.

\subsection{PM Exposure Levels in Americas}

Hess et al. (2010) evaluated waiting passengers' exposure to $\mathrm{PM}_{2.5}$ inside and outside bus stations in Buffalo, New York by investigating $840 \mathrm{~min}$ of concurrent exposure [66]. They used a multivariate regression model to assess the relationship between $\mathrm{PM}_{2.5}$ exposure and three vectors of determinants including time and location, environmental factors, and physical setting and location. This model suggested that personal exposure to $\mathrm{PM}_{2.5}$ inside the bus shelters was $17.24 \pm 16.60 \mu \mathrm{g} / \mathrm{m}^{3}$, higher than that outside by $14.72 \pm 8.19 \mu \mathrm{g} / \mathrm{m}^{3}$, due to cigarette smoking. The cigarette smoking, which was found to increase $\mathrm{PM}_{2.5}$ exposure to $22.74 \mu \mathrm{g} / \mathrm{m}^{3}$, was the largest factor enhancing personal exposure while passengers wait at bus stations.

In addition, Moore et al. (2012) also conducted an empirical study of PM exposure for passengers waiting at bus stations in Portland, USA [7]. This study compared the personal exposure at two-sided bus shelters which either face roadway traffic or are oriented away from it. The mean values of $\mathrm{PM}_{10}$ and $\mathrm{PM}_{2.5}$ were 25.00 and $21.97 \mu \mathrm{g} / \mathrm{m}^{3}$ relative to independent variables (e.g., shelter orientation, vehicle flow, wind speed, wind direction, temperature, and humidity). Particularly, with an opening 
oriented towards the roadway, the PM concentration inside the bus shelter was higher than that outside. By contrast, the inside of shelters oriented away from roadway traffic had a lower PM concentration than did the outside. Besides, they reported that vehicle flow showed a significant correlation with PM concentration at bus stations.

The correlation of particulate air pollution at bus stops and vascular reactivity in Ottawa, Canada was demonstrated by Dales et al. [8]. In this study, which included 39 healthy volunteers waiting outside bus shelters for $2 \mathrm{~h}$, the flow-mediated vasodilation (FMD) of the brachial artery increased with in $\mathrm{PM}_{2.5}$ exposure. The authors indicated that a $30 \mu \mathrm{g} / \mathrm{m}^{3}$ increase in $\mathrm{PM}_{2.5}$ led to a $0.48 \%$ reduction in FMD.

\subsection{PM Exposure Levels in Asia}

Velasco and Tan (2016) measured the exposure of passengers to particles while waiting at bus stops in the humid and hot weather of Singapore [9]. In this study, they used a set of portable battery-operated sensors to evaluate traffic particle concentrations at the bus stations. It was estimated that traffic exhaust particles at these bus stops contained mostly $\mathrm{PM}_{1}, \mathrm{PM}_{2.5}$, and $\mathrm{PM}_{10}$ ranging from $89 \%$ to $94 \%$ of total exhaust particles. Although waiting times at bus stations in Singaporean are generally short (average $20 \mathrm{~min}$ a roundtrip per day), commuters might be exposed to concentrations $1.5-3$ times greater than reported by local authorities with an average $P_{2.5}$ exposure of $23-57 \mu \mathrm{g} / \mathrm{m}^{3}$.

In China, $\mathrm{Xu}$ et al. conducted an empirical study on individual and population intake fractions of PM at bus stops to estimate personal exposure as well as the correlation between diesel PM and emissions [6]. The PM pollution was mainly caused by diesel vehicle emission (28\%), crustal dust $(26 \%)$, coal combustion (22\%), cement $(4.9 \%)$, and other sources. In addition, the $\mathrm{PM}_{10}$ concentration at bus stations during rush hours, at $254 \pm 128 \mu \mathrm{g} / \mathrm{m}^{3}$, was much too high, compared with ambient $24 \mathrm{~h}$ and intercity bus terminal PM concentrations of 103 and $80 \mu \mathrm{g} / \mathrm{m}^{3}$, respectively. They also pointed out that bus stations near roadsides could accumulate high particles, thus causing high level of exposure to direct vehicle emissions.

In addition to city center bus stops, intercity bus terminals can also accumulate high particle levels, especially in waiting areas. Cheng et al. determined short-term exposures to $\mathrm{PM}_{10}$ and $\mathrm{PM}_{2.5}$ for passengers at a Taipei bus terminal station [76]. This study estimated $\mathrm{PM}_{10}$ and $\mathrm{PM}_{2.5}$ levels of $74 \pm 30.5$ and $50.75 \pm 26.25 \mu \mathrm{g} / \mathrm{m}^{3}$, respectively, which had been exhausted directly from cruising and idling buses and outside traffic surrounding waiting areas. In another study, Salama et al. (2017) assessed air quality in bus terminal stations in the Kingdom of Saudi Arabia by applying dust collection calibrated devices [77]. By this method, $\mathrm{PM}_{10}, \mathrm{PM}_{4}, \mathrm{PM}_{2.5}$, and $\mathrm{PM}_{1}$ levels were measured as $185.1 \pm 21.5$, $118.8 \pm 18.4,112.8 \pm 13.3$, and $85.5 \pm 9.9 \mu \mathrm{g} / \mathrm{m}^{3}$ in the morning and $172.3 \pm 4.8,137.8 \pm 18.2$, $93.8 \pm 10.23$, and $99.2 \pm 4.3 \mu \mathrm{g} / \mathrm{m}^{3}$ in the evening, respectively, as compared with Saudi Arabia's standard air quality guidelines.

\section{Future Directions for Reduction in Personal PM Exposure}

\subsection{Pollution Prevention and Control}

PM emissions can be minimized by pollution prevention and control technologies. Some typical regulations and air quality management actions have been applied to reduce pollution from concerning sources (traffic, industry, and human activities). Pollution prevention includes choosing clean fuels (natural gas) instead of diesel fuel, whose substitution can reduce the formation of secondary particles $\left(\mathrm{NO}_{2}\right.$ and $\left.\mathrm{NH}_{3}\right)$ in traffic emission; utilizing cleaner processes such as advanced coal combustion technologies (coal gasification and fluidized-bed combustion) that may lower concentrations of products by incomplete combustion, and replacing older devices with cleaner ones enables better burning and fewer PM emissions [78,79]. Particularly, in order to reduce personal exposure indoors and outdoors, especially at bus stations, passengers should avoid smoking in bus shelters, reduce traveling during rush hour, and avoid outdoor activities when pollution levels are high [80]. 
In addition, a variety of PM-removal technologies with different physical and economic characteristics have been applied, such as impingement separators and electrostatic precipitators. Impingement separators rely on the inertial properties of the particles to separate them from the carrier gas stream, thereby collecting medium-size and coarse particles, while electrostatic precipitators show a high efficiency in collecting $\mathrm{PM}_{2.5}$ with well-designed, well-operated, and well-maintained systems, that can remove PM by using an electrostatic field to attract particles onto their electrodes [79].

\subsection{Forecasting of PM Pollution}

In order to avoid high pollution exposure, commuters should check current and forecasted air quality levels before undertaking outdoor and public transport. Forecasting of pollution is an important tool for taking effective pollution control measures that can provide an early warning against harmful air pollutants [81]. Among these various predictive models, modes of artificial intelligence such as artificial neural network (ANN) and adaptive neuro-fuzzy inference systems (ANFIS) models are classic methods used to forecast air pollution quantitatively [81,82].

\subsubsection{Artificial Neural Network (ANN) Models}

ANN is a powerful data modeling method with proven efficacy in solving complex problems in the fields of alignment, prediction, and classification [82]. A number of recent studies have used ANN models to predict hourly or daily PM concentrations with low error values [82-85]. It is a mathematical model based on a collection of artificial neurons connected or functionally-related to each other, which behave like neurons in the biological brain [83,85]. Generally, its architecture consists of arrangement of neurons within several layers including an input layer, hidden layers, and an output layer (Figure 8); all neurons in a layer are connected to all neurons in adjacent layers by synaptic weights acting as signaling coefficients on the corresponding connections $[83,85,86]$. In ANN models, signals are transmitted from the first layer (the input layer) to the final layer (the output layer); the connecting signals between artificial neurons are real numbers, and the output of each of the artificial neurons is analyzed by a number of linear or non-linear statistical techniques [83,87]. In addition, ANN models have been developed on two popular neural network architectures including the Multilayer Perceptron (MLP) neural network and the Radial Basis Function (RBF) network.

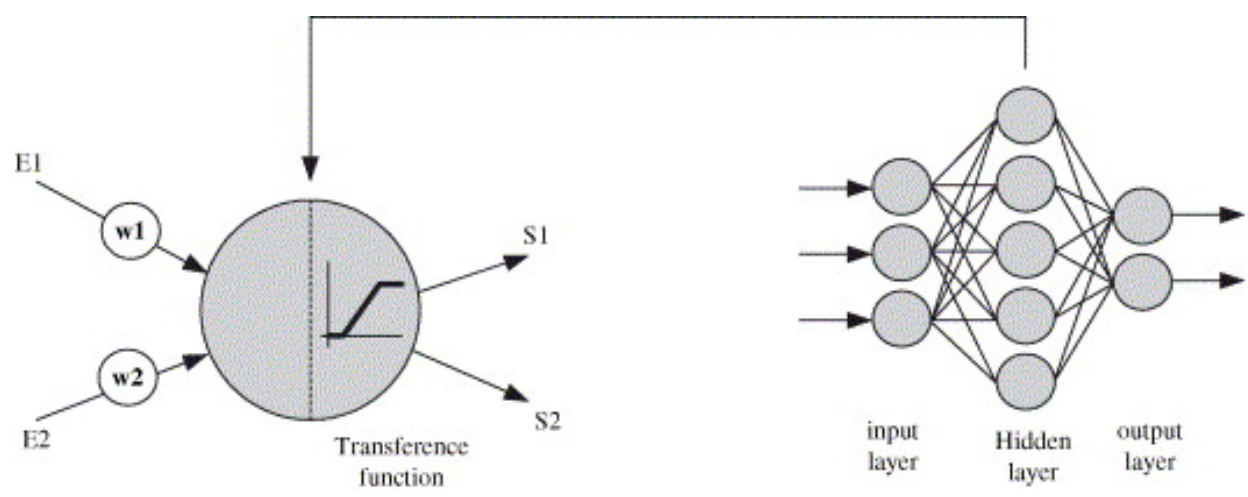

Figure 8. Artificial neural network (ANN) structure [82]. "Reproduced with permission from Ordieres et al., Environmental Modelling \& Software; published by Elsevier, 2005)”.

Multilayer Perceptron Neural Network (MLP)

MLP, along with feed-forward network (FFN), is the most popular neural network architecture, and is used to analyze the relationships between different variables and to predict the outcome of response variables. Used when the number of independent variables is greater than one, the MLP model with the given i observation is shown in Equation (1),

$$
\mathrm{Y}=\beta_{0}+\sum_{i=1}^{n} \beta_{i} X_{i}+\varepsilon_{i}
$$


where $\mathrm{X}_{i}$ is the value of the input variable $\mathrm{I}, \mathrm{Y}$ is the prediction calculated by a linear combination, the constant $\beta_{0}$ and the regression coefficients $\beta_{i}$ being computed by ordinary least-squares equation, and $\varepsilon$ is a residual error [83].

The MLP model consists of three layers of neurons, each of which uses a linear combination function, and the input signal is processed in several steps in one direction: the input variables activate the first layer (input layer), the signal is then transmitted to the second layer (hidden layer), where this signal is elaborated, and finally, the activation states of the second layer are then passed to the last layer $[82,83]$. In detail, the number of neurons in the first layer corresponds to the number of input variables, the number of nodes in the second layer is chosen to limit the total number of weights that can avoid an important problem known as overtraining of the network, and the last layer includes a single neuron representing the output of the network [83].

Supervised training algorithms such as backpropagation (BP) play an important role in the ANN network. With BP, also known as "training", repetitive inputs are presented to the neural network, the output is compared to the desired output, and an error is evaluated. After BP, the neural network adjusts the weights to reduce the error with each iteration and to improve outcomes closer and closer to the desired output. Indeed, this training is relatively easy and provides good support for predictive applications [82].

In fact, in a study of Feng et al. (2015), the MLP type of back-propagation neural network was applied to forecast $\mathrm{PM}_{2.5}$ pollution based on respective pollutant predictors as well as meteorological forecast variables as input data [88]. In this study, $85 \%$ of data was set for training, and the remaining data was used for testing. There were 10 variables in the first layer, as shown in Figure 9 (PM concentration, temperature max and min, wind, humidity, neighbor weighted, general condition, month of year, and day of week), and the prognostic predictors (wind, temperature, and humidity) were extracted from the predicted values published by meteorological authorities instead of real-time values. The hidden layer of this neural network contained 8 neurons that can obtain the best validation data for an optimal MLP structure. It has been reported that with the high daily level of $\mathrm{PM}_{2.5}$ in China, applications of this neural network can achieve an average accurate prediction of $90 \%$ compared to real-time values of $\mathrm{PM}_{2.5}$ concentrations prevalent at the same time.

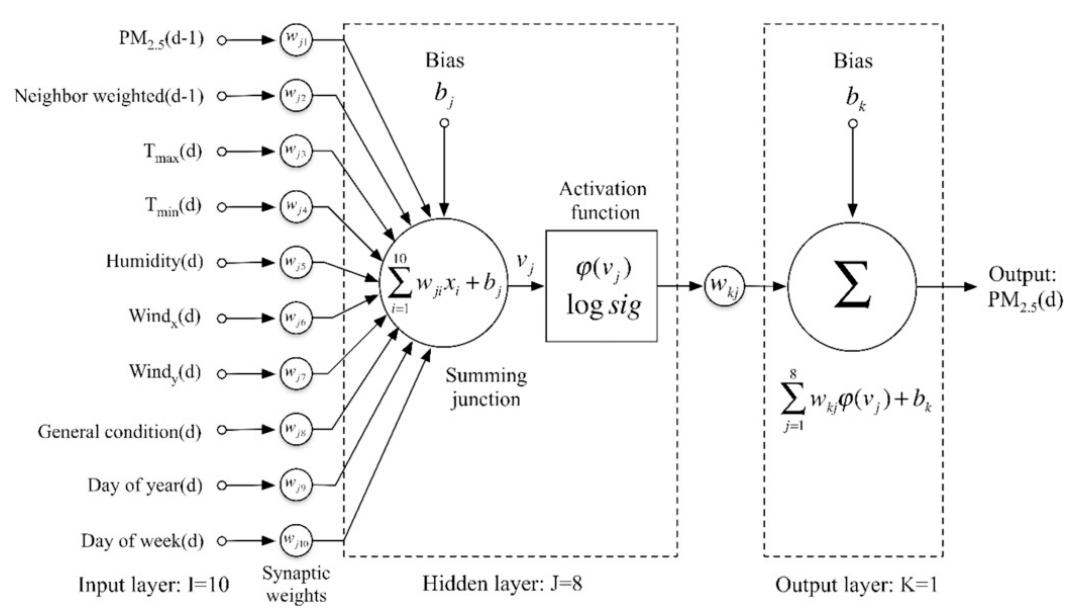

Figure 9. Architecture of Multilayer Perceptron (MLP)-type neural network [88].

Furthermore, Bianofiore et al. developed a recurrent architecture based on the MLP model for analysis and forecast of $\mathrm{PM}_{10}$ and $\mathrm{PM}_{2.5}$ [83]. In this model, the input layer was set with the activation state of the nodes in the intermediate layers, the processed signal was then transmitted back to the input level, and the neurons in the second layer contained the compressed information on the meteorological and chemical parameters of the previous time step, and so this architecture displayed a dynamic memory of the types of events provided as the inputs of the network. Meteorological conditions, real-time $\mathrm{PM}_{10}$ and $\mathrm{PM}_{2.5}$ concentrations from training data, and $\mathrm{CO}$ concentrations were 
used as the inputs to simulate $\mathrm{PM}_{10}$ and $\mathrm{PM}_{2.5}$ concentrations via the recurrent neural network. It was determined that this model is a potential tool for obtainment of the real-time $\mathrm{PM}_{10}$ and $\mathrm{PM}_{2.5}$ concentration information.

\section{Radial Basis Function (RBF) Neural Network}

Radial basis function (RBF) also is an effective feed-forward neural network. Although less well-known than the MLP model, the main advantages of the RBF network are its affording of the minimum approximating error of any function as well as the global optimum, and its generally much faster training $[83,89-91]$. Therefore, it has been widely used in a considerable number of applications (e.g., classification, regression problems, function approximation, prediction, and signal processing) with good results.

The RBF network consists of three different layers (Figure 10). The first layer has the same structure and function as the input layer of the MLP network, including various input neurons connected to each input, and the input neurons then feed the values to each of the neurons in the second layer (hidden layer). The main difference between RBF and other types of neural network is the hidden layer $[83,91]$. The hidden layer is a center nonlinear function that is symmetric to the local distribution, and includes a width parameter and a center position with the RBF based on the Gaussian distribution function (Equation (2)) [90,91]:

$$
\varnothing_{j}(x)=\exp \left(-\frac{\left\|x-\mu_{j}\right\|^{2}}{2 \sigma_{j}^{2}}\right)
$$

where $\varnothing_{j}$ is the nonlinear function of unit $j$ in the RBF, $\chi$ is the input data vector, $\mu_{j}$ is the center of unit $j$ in the RBF unit, and $\sigma_{j}$ is the spread of the Gaussian basis function with respect to unit $j$.

The third layer of the RBF network is connected by linear units and creates output $[83,89]$. The extracted signal from the hidden layer is processed and the problem is solved by learning processes in the output layer. There are two sets of weights measuring the distance concerning input data and the output layer. In the first set of weights, the radial distance is computed for every unit between the non-linear inputs and the center of the basis function using the Euclidean distance algorithm, while the second weight is combined with the activation function known as the RBF, which generates outputs in the linear form [91]. The output can forecast pollutant concentrations following Equation (3):

$$
\mathrm{Y}_{\mathrm{k}(\mathrm{x})}=\sum_{j=1}^{\mathrm{M}} \mathrm{W}_{\mathrm{kj}} \varnothing_{j}(\mathrm{X})+\mathrm{W}_{\mathrm{k} 0}
$$

where $\mathrm{M}$ is the number of basic functions, $\mathrm{x}$ is the output data vector, $\mathrm{W}_{\mathrm{kj}}$ is the connection weight between the basis function and the output layer, $\varnothing_{j}$ is the nonlinear function of unit $j$ in the RBF, and $\mathrm{W}_{\mathrm{k} 0}$ is the weighted connection in the output layer.

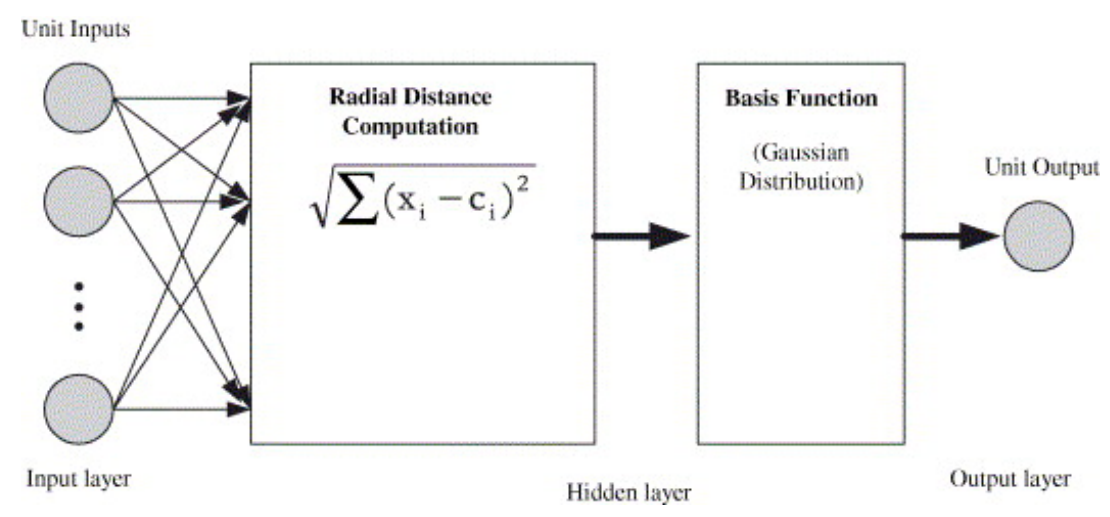

Figure 10. Radial basis function (RBF) structure [82]. "Reproduced with permission from Ordieres et al., Environmental Modelling \& Software; published by Elsevier, 2005)". 


\subsubsection{Adaptive Neuro-Fuzzy Inference Systems (ANFIS) Model}

The adaptive neuro-fuzzy inference systems (ANFIS) model, proposed by Jang et al. (1993), is a hybrid architecture composed of fuzzy inference systems (FIS) enhanced with ANN features [92]. This model compensates for the disadvantages of fuzzy inference systems such as trial-error methods in tuning membership functions parameters, high time-consumption in design, a continuous and complete rule base, and a lack of standard methods for transforming human knowledge into a rule base [93]. On the other hand, the main advantages of the ANFIS model are the lack of any requirement for a mathematical model, its simulation of human thinking, and its simple interpretation of results $[93,94]$.

The ANFIS architecture has five layers according to Takagi-Sugeno rules (Figure 11) [94]. The first layer (adaptive) forms the premise parameters. In the second layer, the products of the involved membership function are computed. Then, in the third layer, the sum of inputs is standardized. In the fourth layer, the adaptive if-node computes the contribution of if-then rules to the ANFIS output and forms the consequence parameters, and the fifth and final layer, sum all of the inputs [94,95].

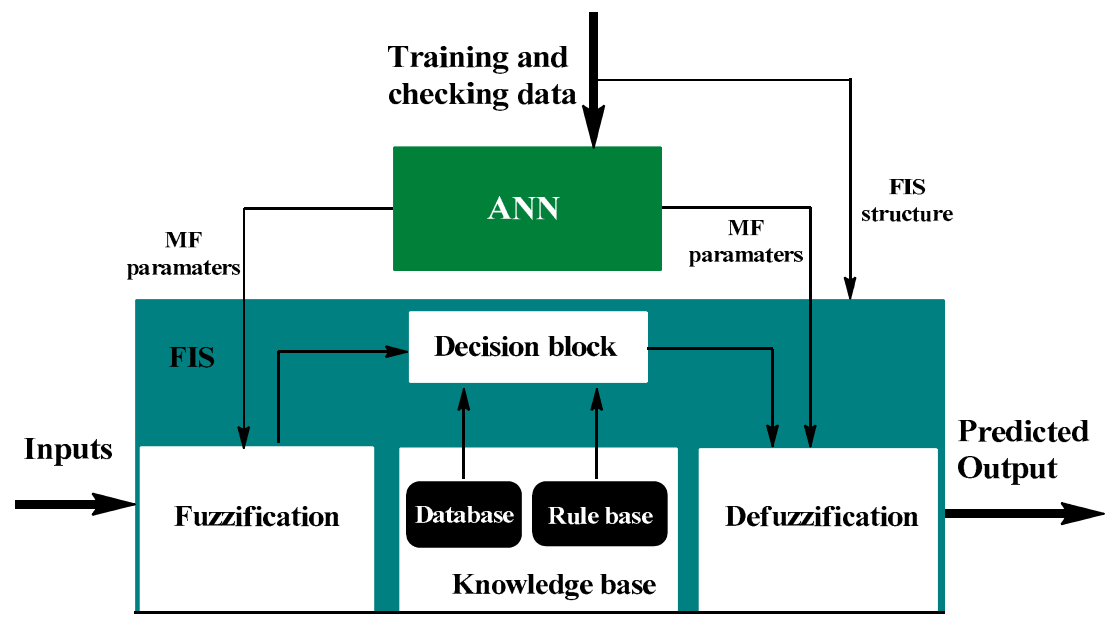

Figure 11. Adaptive neuro-fuzzy inference systems (ANFIS) structure [94].

In addition, a FIS structure consists of three main components, including a rule base, a database, and a reasoning mechanism [96]. The rule base has enough if-then rules for the scope of input variables, while the database determines membership functions applied in fuzzy rules, and the reasoning mechanism is responsible for an inference procedure [96]. Besides, the ANN portion in this architecture can improve membership functions related to the FIS structure based on its training mode, according to a training and checking dataset [93]. The training process is based on a hybrid learning algorithm or a BP algorithm. The hybrid learning algorithm defines premise parameters with a gradient method and consequence parameters with a least square model. With the BP algorithm, error signals are transmitted back, and new premise parameters are calculated using the gradient method.

In fact, Domanska and Wojtylak applied the ANFIS model to forecast concentrations of $\mathrm{CO}, \mathrm{SO}_{2}$, and especially $\mathrm{PM}_{10}$ and $\mathrm{PM}_{2.5}$ pollution. Meteorological data (e.g., time horizon, weather forecast, meteorological situation, and pollution concentration) in Poland were defined as inputs. It was estimated that the ANFIS model forecasted $\mathrm{PM}_{10}$ and $\mathrm{PM}_{2.5}$ concentrations for $24-36 \mathrm{~h}$ with the lowest error value [97]. In another study, Polat and Durduran predicted daily air pollution levels including $\mathrm{PM}_{10}$ concentrations in Turkey using a combined ANFIS/output-dependent data scaling (ODDS) network model [98]. $\mathrm{PM}_{10}$ forecast was contributed by meteorological variables (e.g., temperature, humidity, pressure, and wind velocity attributes) as input data, as training data, and actual $\mathrm{PM}_{10}$ concentrations from the air quality statistics database of the Turkish Statistical Institute. The combined ANFIS/ODDS model was demonstrated to be an effective $\mathrm{PM}_{10}$ prediction method (Figure 12). 


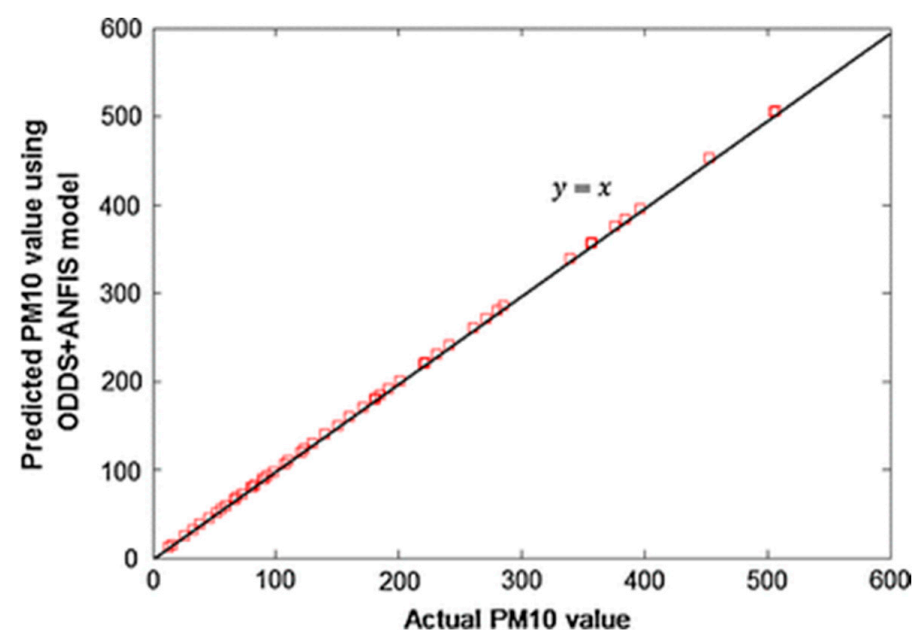

Figure 12. Predicted and actual $\mathrm{PM}_{10}$ concentration values and their relationship according to combined ANFIS/ output-dependent data scaling (ODDS) model [98]. "Reproduced with permission from Polat and Durduran, Neural Computing \& Applications; published by Springer Nature, 2011)".

\section{Limitation of Study}

The limitation of this review is the relatively small number of individual studies evaluating personal exposure while passengers are waiting at bus stations, especially in heavily polluted countries. This fact could have been the cause of some negligible estimates.

\section{Conclusions}

This review identifies levels and factors affecting PM pollution at bus stations and calculates passenger exposure while waiting at bus stations as well as the health effects of such exposure. PM pollution at bus stations is primarily attributable to the combustion of fuel in vehicles, the wear of vehicle components (e.g., tires and brakes), the suspension of road dust, cigarette smoking, and industrial emissions. In addition, meteorological factors including wind speed, vehicle flow, temperature, relative humidity, pressure, rain volume, and cloudiness as well as the design and the direction of bus stations also influence distributions of PM inside or outside bus stops. It was proven that bus stops can accumulate high PM levels, thereby enhancing personal exposure to PM and leading to related diseases such as CVD, respiratory health effects, and diabetes. In order to accurately predict PM pollution, some predictive methods have been developed, typically ANN and ANFIS networks. In which, ANN is a powerful data modeling method with proven efficacy in solving complex problems in the fields of alignment, prediction, and classification, while the ANFIS model has several advantages such as non-requirement of a mathematical model, simulation of human thinking, and simple interpretation of results relative to other predictive methods. These networks, based on real PM concentration databases from local authorities, relative meteorological parameters, and some statistical software, endow PM forecasts with small error values. Consequently, development of air quality prediction networks at bus stops, which potentially can reduce health risks to a minimum, is both feasible and necessary. Future research should focus on evaluation of personal exposure during travels by public transportation, especially at bus stations.

Author Contributions: Y.-C.L. planned the study and contributed the main ideas; L.T.N.N. was principally responsible for the writing of the manuscript; Y.-C.L., D.P., M.K. and V.K.H.B. commented on and revised the manuscript.

Funding: This research received no external funding.

Acknowledgments: This subject is also supported by Ministry of Environment as "Korea Environmental industry \& Technology institute (KEITI) (NO.2018000120004)".

Conflicts of Interest: The authors declare that they have no competing interests. 


\section{References}

1. Knibbs, L.D.; Cole-Hunter, T.; Morawska, L. A review of commuter exposure to ultrafine particles and its health effects. Atmos. Environ. 2011, 45, 2611-2622. [CrossRef]

2. Brook, R.D.; Rajagopalan, S.; Pope, C.A.; Brook, J.R.; Bhatnagar, A.; Diez-Roux, A.V.; Holguin, F.; Hong, Y.; Luepker, R.V.; Mittleman, M.A.; et al. Particulate matter air pollution and cardiovascular disease: An update to the scientific statement from the American heart association. Circulation 2010, 121, 2331-2378. [CrossRef] [PubMed]

3. Rajagopalan, S.; Brook, R.D. Air pollution and Type 2 diabetes: Mechanistic insights. Diabetes 2012, 61, 3037-3045. [CrossRef] [PubMed]

4. Xing, Y.F.; Xu, Y.H.; Shi, M.H.; Lian, Y.X. The impact of $\mathrm{PM}_{2.5}$ on the human respiratory system. J. Thorac. Dis. 2016, 8, E69-E74. [CrossRef] [PubMed]

5. Ristovski, Z.D.; Miljevic, B.; Surawski, N.C.; Morawska, L.; Fong, K.M.; Goh, F.; Yang, I.A. Respiratory health effects of diesel particulate matter. Respirology 2012, 17, 201-212. [CrossRef] [PubMed]

6. Xu, J.; Jin, T.; Miao, Y.; Han, B.; Gao, J.; Bai, Z.; Xu, X. Individual and population intake fractions of diesel particulate matter (DPM) in bus stop microenvironments. Environ. Pollut. 2015, 207, 161-167. [CrossRef] [PubMed]

7. Moore, A.; Figliozzi, M.A.; Monsere, C.M. An empirical study of particulate matter exposure for passengers waiting at bus stop shelters in Portland, Oregon, USA. Civil Environ. Eng. Com. 2012, 1-20. [CrossRef]

8. Dales, R.; Liu, L.; Szyszkowicz, M.; Dalipaj, M.; Willey, J.; Kulka, R.; Ruddy, T.D. Particulate air pollution and vascular reactivity: The bus stop study. Int. Arch. Occup. Environ. Health 2007, 81, 159-164. [CrossRef]

9. Velasco, E.; Tan, S.H. Particles exposure while sitting at bus stops of hot and humid Singapore. Atmos. Environ. 2016, 142, 251-263. [CrossRef]

10. Cevallos, J.B. Spatial Variability of Particulate Matter (PM2.5) in the Ambient Air on the Campus of the University of Manchester; School of Environment, Education and Development: Manchester, UK, 2014; pp. 1-46.

11. Wikipedia. Particulates. Available online: https://en.wikipedia.org/wiki/Particulates (accessed on 20 September 2018).

12. United States Environmental Protection Agency. Particulate Matter (PM) Basics. Available online: https: //www.epa.gov/pm-pollution/particulate-matter-pm-basics\#PM (accessed on 17 September 2018).

13. WHO. Health Aspects of Air Pollution with Particulate Matter, Ozone, and Nitrogen Dioxide; 2003. Available online: http://www.euro.who.int/_data/assets/pdf_file/0005/112199/E79097.pdf (accessed on 7 September 2018).

14. Esworthy, R. Air Quaility: EPA's 2013 Changes to the Particulate Matter (PM) Standard; 2015. Available online: https: / fas.org/sgp/crs/misc/R42934.pdf (accessed on 15 September 2018).

15. Hasheminassab, S.; Daher, N.; Schauer, J.J.; Sioutas, C. Source apportionment and organic compound characterization of ambient ultrafine particulate matter (PM) in the Los Angeles basin. Atmos. Environ. 2013, 79, 529-539. [CrossRef]

16. Nielsen, E.; Sidhu, B. Air Quality at Bus Stop Microenvironments in a Metro Vancouver Urban and Suburban Area. Environ. Health J. 2014. Available online: https://circuit.bcit.ca/repository/islandora/ object/repository\%3A41 (accessed on 17 December 2018).

17. Harrison, R.M.; Thornton, C.A.; Lawrence, R.G.; Mark, D.; Kinnersley, R.P.; Ayres, J.G. Personal exposure monitoring of particulate matter, nitrogen dioxise, and carbon monoxide, including sysceptible groups. Occup. Environ. Med. 2002, 59, 671-679. [CrossRef] [PubMed]

18. Srimuruganandam, B.; Shiva Nagendra, S.M. Source characterization of $\mathrm{PM}_{10}$ and $\mathrm{PM}_{2.5}$ mass using a chemical mass balance model at urban roadside. Sci. Total Environ. 2012, 433, 8-19. [CrossRef] [PubMed]

19. Kim, K.H.; Kabir, E.; Kabir, S. A review on the human health impact of airborne particulate matter. Environ. Int. 2015, 74, 136-143. [CrossRef] [PubMed]

20. Onat, B.; Stakeeva, B. Personal exposure of commuters in public transport to $\mathrm{PM}_{2.5}$ and fine particle counts. Atmos. Pollut. Res. 2013, 4, 329-335. [CrossRef]

21. Zhang, Q.; Zhu, Y. Performance of school bus retrofit systems: Ultrafine particles and other vehicular pollutants. Environ. Sci. Technol. 2011, 45, 6475-6482. [CrossRef] [PubMed]

22. Air Pollution Emissions in the UK. Available online: http://www.air-quality.org.uk/08.php (accessed on 28 September 2018). 
23. Cooper, E.; Arioli, M.; Carrigan, A.; Jain, U. Exhaust Emissions of Transit Buses. EMBARQ. 2002. Available online: https://wrirosscities.org/sites/default/files/Exhaust-Emissions-Transit-Buses-EMBARQ.pdf (accessed on 17 September 2018).

24. Diesel Engines and Public Health. Available online: https://www.ucsusa.org/clean-vehicles/vehicles-airpollution-and-human-health/diesel-engines\#.W5pcKlx4lph (accessed on 2 October 2018).

25. Air Pollution Particulate Matter. Available online: https://www.greenfacts.org/en/particulate-matter-pm/ level-2/01-presentation.htm (accessed on 10 October 2018).

26. Casati, R.; Scheer, V.; Vogt, R.; Benter, T. Measurement of nucleation and soot mode particle emission from a diesel passenger car in real world and laboratory in situ dilution. Atmos. Environ. 2007, 41, 2125-2135. [CrossRef]

27. Brown, J.S.; Gordon, T.; Price, O.; Asgharian, B. Thoracic and respirable particle definitions for human health risk assessment. Part. Fibre Toxicol. 2013, 10, 1-12. [CrossRef]

28. Atkinson, R.W.; Fuller, G.W.; Anderson, H.R.; Harrison, R.M.; Armstrong, B. Urban ambient particle metrics and health: A time-series analysis. Epidemiology 2010, 21, 501-511. [CrossRef]

29. Londahl, J.; Pagels, J.; Swietlicki, E.; Zhou, J.; Ketzel, M.; Massling, A.; Bohgard, M. A set-up for field studies of respiratory tract deposition of fine and ultrafine particles in humans. J. Aerosol Sci. 2006, 37, 1152-1163. [CrossRef]

30. Hu, D.; Jiang, J. PM 2.5 pollution and risk for lung cancer: A rising issue in China. J. Environ. Prot. 2014, 5, 731-738. [CrossRef]

31. Valavanidis, A.; Fiotakis, K.; Vlachogianni, T. Airborne particulate matter and human health: Toxicological assessment and importance of size and composition of particles for oxidative damage and carcinogenic mechanisms. J. Environ. Sci. Health C 2008, 26, 339-362. [CrossRef] [PubMed]

32. Anderson, J.O.; Thundiyil, J.G.; Stolbach, A. Clearing the air: A review of the effects of particulate matter air pollution on human health. J. Med. Toxicol. 2012, 8, 166-175. [CrossRef] [PubMed]

33. McCarthy, N. Air Pollution Contributed to More than 6 Million Deaths in 2016. Available online: https:/ / www.forbes.com/sites/niallmccarthy/2018/04/18/air-pollution-contributed-to-more-than-6million-deaths-in-2016-infographic/\#256f259a13b4 (accessed on 27 September 2018).

34. WHO. Mortality and Burden of Disease from Ambient Air Pollution. Available online: http:/ /www.who. int/gho/phe/outdoor_air_pollution/burden_text/en/ (accessed on 12 October 2018).

35. WHO. Health Effects of Particulate Matter. 2013. Available online: http://www.unece.org/environmentalpolicy / conventions / envlrtapwelcome/ publications / others/2013/health-effects-of-particulate-matter. html (accessed on 12 October 2018).

36. Sidney, S.; Quesenberry, C.P., Jr.; Jaffe, M.G.; Sorel, M.; Nguyen, H.M.N.; Kushi, L.H.; Go, A.S.; Rana, J.S. Recent trends in cardiovascular mortality in the United States and public health goals. JAMA Cardiol. 2016, 1, 594-599. [CrossRef] [PubMed]

37. Nordqvist, C. What Is Cardiovascular Disease? Available online: https://www.medicalnewstoday.com/ articles /257484.php (accessed on 10 October 2018).

38. Du, Y.; Xu, X.; Chu, M.; Guo, Y.; Wang, J. Air particulate matter and cardiovascular disease: The epidemiological, biomedical and clinical evidence. J. Thorac. Dis. 2016, 8, E8-E19. [CrossRef] [PubMed]

39. Martinelli, N.; Olivieri, O.; Girelli, D. Air particulate matter and cardiovascular disease: A narrative review. Eur. J. Intern. Med. 2013, 24, 295-302. [CrossRef]

40. Nelin, T.D.; Joseph, A.M.; Gorr, M.W.; Wold, L.E. Direct and indirect effects of particulate matter on the cardiovascular system. Toxicol. Lett. 2012, 208, 293-299. [CrossRef]

41. Shrey, K.; Suchit, A.; Deepika, D.; Shruti, K.; Vibha, R. Air pollutants: The key stages in the pathway towards the development of cardiovascular disorders. Environ. Toxicol. Pharmacol. 2011, 31, 1-9. [CrossRef]

42. Simkhovich, B.Z.; Kleinman, M.T.; Kloner, R.A. Air pollution and cardiovascular injury epidemiology, toxicology, and mechanisms. J. Am. Coll. Cardiol. 2008, 52, 719-726. [CrossRef]

43. Brook, R.D. Cardiovascular effects of air pollution. Clin. Sci. 2008, 115, 175-187. [CrossRef]

44. Pope, C.A.; Muhlestein, J.B.; May, H.T.; Renlund, D.G.; Anderson, J.L.; Horne, B.D. Ischemic heart disease events triggered by short-term exposure to fine particulate air pollution. Circulation 2006, 114, 2443-2448. [CrossRef] [PubMed]

45. Samet, J.; Dominici, F.; Curriero, F.; Coursac, I.; Zeger, S. Fine particulate air pollution and mortality in 20 US cities 1987-1994. NEJM 2000, 343, 1742-1749. [CrossRef] [PubMed] 
46. Yin, P.; He, G.; Fan, M.; Chiu, K.Y.; Fan, M.; Liu, C.; Xue, A.; Liu, T.; Pan, Y.; Mu, Q.; et al. Particulate air pollution and mortality in 38 of China's largest cities. BMJ 2017, 356, 667. [CrossRef] [PubMed]

47. Miller, K.A.; Siscovick, D.S.; Sheppard, L.; Shepherd, K. Lomg-term exposure to air pollution and incidence of cardiovascular events in women. NEJM 2007, 356, 447-458. [CrossRef] [PubMed]

48. Dominici, F.; Peng, R.D.; Bell, M.L.; Luu Pham, M.; McDermott, A.; Zeger, S.L.; Samet, J.M. Fine particulate air pollution and hospital admission for cardiovascular and respiratory diseases. JMAM 2006, 295, 1127-1134. [CrossRef] [PubMed]

49. Neas, L.M. Fine particulate matter and cardiovascular disease. Fuel Sci. Technol. 2000, 65, 57-67. [CrossRef]

50. Particle Pollution and Respiratory Effects. Available online: https:/ /www.epa.gov/particle-pollution-andyour-patients-health/health-effects-pm-patients-lung-disease (accessed on 16 October 2018).

51. Wu, J.Z.; Ge, D.D.; Zhou, L.F.; Hou, L.Y.; Zhou, Y.; Li, Q.Y. Effects of particulate matter on allergic respiratory diseases. Chronic Dis. Transl. Med. 2018, 4, 95-102. [CrossRef]

52. Xu, X.-C.; Li, Z.-Y.; Chen, H.-P.; Zhou, J.-S.; Wang, Y.; Shen, H.-H.; Chen, Z.-H. Cellular mechanisms of the adverse respiratory health effect induced by ambient particulate matter: A review and perspective. J. Respir. Med. Lung Dis. 2017, 2, 1-5.

53. Karakatsani, A.; Analitis, A.; Perifanou, D.; Ayres, J.G.; Harrison, R.M.; Kotronarou, A.; Kavouras, I.G.; Pekkanen, J.; Hämeri, K.; Kos, G.P.; et al. Particulate matter air pollution and respiratory symptoms in individuals having either asthma or chronic obstructive pulmonary disease. A European multicenter panel study. Environ. Health 2012, 12, 1-15. [CrossRef]

54. Guo, C.; Zhang, Z.; Lau, A.K.H.; Lin, C.Q.; Chuang, Y.C.; Chan, J.; Jiang, W.K.; Tam, T.; Yeoh, E.-K.; Chan, T.-C.; et al. Effect of long-term exposure to fine particulate matter on lung function decline and risk of chronic obstructive pulmonary disease in taiwan: A longitudinal, cohort study. Lancet Planet. Health 2018, 2, 114-125. [CrossRef]

55. Jo, E.J.; Lee, W.S.; Jo, H.Y.; Kim, C.H.; Eom, J.S.; Mok, J.H.; Kim, M.H.; Lee, K.; Kim, K.U.; Lee, M.K.; et al. Effects of particulate matter on respiratory disease and the impact of meteorological factors in Busan, Korea. Respir. Med. 2017, 124, 79-87. [CrossRef] [PubMed]

56. Hansen, A.B.; Ravnskjaer, L.; Loft, S.; Andersen, K.K.; Brauner, E.V.; Baastrup, R.; Yao, C.; Ketzel, M.; Becker, T.; Brandt, J.; et al. Long-term exposure to fine particulate matter and incidence of diabetes in the danish nurse cohort. Environ. Int. 2016, 91, 243-250. [CrossRef] [PubMed]

57. Liang, R.; Zhang, B.; Zhao, X.; Ruan, Y.; Lian, H.; Fan, Z. Effect of exposure to $\mathrm{PM}_{2.5}$ on blood pressure: A systematic review and meta-analysis. J. Hypertens. 2014, 32, 2130-2140. [CrossRef] [PubMed]

58. Pearson, J.F.; Bachireddy, C.; Shyamprasad, S.; Goldfine, A.B.; Brownstein, J.S. Association between fine particulate matter and diabetes prevalence in the US. Diabetes Care 2010, 33, 2196-2201. [CrossRef] [PubMed]

59. Weinmayr, G.; Hennig, F.; Fuks, K.; Nonnemacher, M.; Jakobs, H.; Mohlenkamp, S.; Erbel, R.; Jockel, K.H.; Hoffmann, B.; Moebus, S.; et al. Long-term exposure to fine particulate matter and incidence of Type 2 diabetes mellitus in a cohort study: Effects of total and traffic-specific air pollution. Environ. Health 2015, 14, 53. [CrossRef] [PubMed]

60. Wang, B.; Xu, D.; Jing, Z.; Liu, D.; Yan, S.; Wang, Y. Effect of long-term exposure to air pollution on Type 2 diabetes mellitus risk: A systemic review and meta-analysis of cohort studies. Eur. J. Endocrinol. 2014, 171, R173-R182. [CrossRef]

61. Sun, Q.; Yue, P.; Deiuliis, J.A.; Lumeng, C.N.; Kampfrath, T.; Mikolaj, M.B.; Cai, Y.; Ostrowski, M.C.; Lu, B.; Parthasarathy, S.; et al. Ambient air pollution exaggerates adipose inflammation and insulin resistance in a mouse model of diet-induced obesity. Circulation 2009, 119, 538-546. [CrossRef]

62. Xu, X.; Liu, C.; Xu, Z.; Tzan, K.; Zhong, M.; Wang, A.; Lippmann, M.; Chen, L.C.; Rajagopalan, S.; Sun, Q. Long-term exposure to ambient fine particulate pollution induces insulin resistance and mitochondrial alteration in adipose tissue. Toxicol. Sci. 2011, 124, 88-98. [CrossRef]

63. He, D.; Wu, S.; Zhao, H.; Qiu, H.; Fu, Y.; Li, X.; He, Y. Association between particulate matter 2.5 and diabetes mellitus: A meta-analysis of cohort studies. J. Diabetes Investig. 2017, 8, 687-696. [CrossRef]

64. Tecer, L.H.; Süren, P.; Alagha, O.; Karaca, F.; Tuncel, G. Effect of meteorological parameters on fine and coarse particulate matter mass concentration in a coal-mining area in Zonguldak, Turkey. J. Air Waste Manag. Assoc. 2012, 58, 543-552. [CrossRef] 
65. Akyuz, M.; Cabuk, H. Meteorological variations of $\mathrm{PM}_{2.5} / \mathrm{PM}_{10}$ concentrations and particle-associated polycyclic aromatic hydrocarbons in the atmospheric environment of Zonguldak, Turkey. J. Hazard. Mater. 2009, 170, 13-21. [CrossRef]

66. Hess, D.B.; Ray, P.D.; Stinson, A.E.; Park, J. Determinants of exposure to fine particulate matter $\left(\mathrm{PM}_{2.5}\right)$ for waiting passengers at bus stops. Atmos. Environ. 2010, 44, 5174-5182. [CrossRef]

67. Fondelli, M.C.; Chellini, E.; Yli-Tuomi, T.; Cenni, I.; Gasparrini, A.; Nava, S.; Garcia-Orellana, I.; Lupi, A.; Grechi, D.; Mallone, S.; et al. Fine particle concentrations in buses and taxis in Florence, Italy. Atmos. Environ. 2008, 42, 8185-8193. [CrossRef]

68. Unal, Y.S.; Toros, H.; Deniz, A.; Incecik, S. Influence of meteorological factors and emission sources on spatial and temporal variations of $\mathrm{PM}_{10}$ concentrations in Iistanbul metropolitan area. Atmos. Environ. 2011, 45, 5504-5513. [CrossRef]

69. Hussein, T.; Karppinen, A.; Kukkonen, J.; Harkonen, J.; Aalto, P.P.; Hameri, K.; Kerminen, V.-M.; Kulmala, M. Meteorological dependence of size-fractionated number concentrations of urban aerosol particles. Atmos. Environ. 2006, 40, 1427-1440. [CrossRef]

70. Chana, L.Y.; Laua, W.L.; Zoub, S.C.; Cao, Z.X.; Lai, S.C. Exposure level of carbon monoxide and respirable suspended particulate in public transportation modes while commuting in urban area of Guangzhou, China. Atmos. Environ. 2002, 36, 5831-5840. [CrossRef]

71. A.Q.E. Fine Particulate Matter (PM2.5) in the United Kingdom; Department of the Environment in Northern Ireland: 2012. Available online: https:/ / uk-air.defra.gov.uk/assets/documents/reports/cat11/1212141150_ AQEG_Fine_Particulate_Matter_in_the_UK.pdf (accessed on 16 December 2018).

72. Zhang, K.; Batterman, S. Near-road air pollutant concentrations of $\mathrm{CO}$ and $\mathrm{PM}_{2.5}$ : A comparison of MOBILE6.2/CAINE4 and generalized additive models. Atmos. Environ. 2010, 44, 1740-1748. [CrossRef]

73. Moore, A.; Figliozzi, M.; Monsere, C.M. Empirical analysis of expsure to particulate matter at bus stop shelters. Transp. Res. Rec. 2018, 2270, 76-86. [CrossRef]

74. Adams, H.S.; Nieuwenhuijsen, M.J.; Colvile, R.N. Determinants of fine particle $\left(\mathrm{PM}_{2.5}\right)$ personal exposure levels on transport microenvironments, London, UK. Atmos. Environ. 2001, 35, 4557-4566. [CrossRef]

75. Kaur, S.; Nieuwenhuijsen, M.J. Determinants of personal exposure to $\mathrm{PM}_{2.5}$, ultrafine particle counts, and co in a transport microenvironment. Environ. Sci. Technol. 2009, 43, 4737-4743. [CrossRef]

76. Cheng, Y.-H.; Chang, H.-P.; Hsieh, C.-J. Short-term exposure to $\mathrm{PM}_{10}, \mathrm{PM}_{2.5}$, ultrafine particles and $\mathrm{CO}_{2}$ for passengers at an intercity bus terminal. Atmos. Environ. 2011, 45, 2034-2042. [CrossRef]

77. Salama, K.F.; Alhajri, R.F.; Al-Anazi, A.A. Assessment of air quality in bus terminal stations in Eastern province, Kingdom of Saudi Arabia. Int. J. Community Med. Public Health 2017, 4, 1413. [CrossRef]

78. Riffault, V. Particulate Matter Pollution Peakes: Detection and Prevention. Available online: https:// blogrecherche.wp.imt.fr/en/2017/04/19/particulate-matter-pollution-peaks/ (accessed on 16 December 2018).

79. World Bank Group. Pollution Prevention and Abatement Handbook 1998; World Bank: Washington, DC, USA, 1998; pp. 235-239.

80. California Environmental Protection Agency. Facts about Reducing Your Exposure to Particle Pollution; California Environmental Protection Agency: Sacramento, CA, USA, 2014.

81. Bai, L.; Wang, J.; Ma, X.; Lu, H. Air pollution forecasts: An overview. Int. J. Environ. Res. Public. Health 2018, 15, 780. [CrossRef] [PubMed]

82. Ordieres, J.B.; Vergara, E.P.; Capuz, R.S.; Salazar, R.E. Neural network prediction model for fine particulate matter $\left(\mathrm{PM}_{2.5}\right)$ on the US-Mexico border in El Paso (Texas) and Ciudad Juarez (Chihuahua). Environ. Model. Softw. 2005, 20, 547-559. [CrossRef]

83. Biancofiore, F.; Busilacchio, M.; Verdecchia, M.; Tomassetti, B.; Aruffo, E.; Bianco, S.; Di Tommaso, S.; Colangeli, C.; Rosatelli, G.; Di Carlo, P. Recursive neural network model for analysis and forecast of $\mathrm{PM}_{10}$ and $\mathrm{PM}_{2.5}$. Atmos. Pollut. Res. 2017, 8, 652-659. [CrossRef]

84. Li, X.; Peng, L.; Yao, X.; Cui, S.; Hu, Y.; You, C.; Chi, T. Long short-term memory neural network for air pollutant concentration predictions: Method development and evaluation. Environ. Pollut. 2017, 231, 997-1004. [CrossRef] [PubMed]

85. Grivas, G.; Chaloulakou, A. Artificial neural network models for prediction of $\mathrm{PM}_{10}$ hourly concentrations, in the greater area of Athens, Greece. Atmos. Environ. 2006, 40, 1216-1229. [CrossRef]

86. Perez, P.; Reyes, J. An integrated neural network model for $\mathrm{PM}_{10}$ forecasting. Atmos. Environ. 2006, 40, 2845-2851. [CrossRef] 
87. Wikipedia. Artificial Neural Network. Available online: https://en.wikipedia.org/wiki/Artificial_neural_ network (accessed on 17 October 2018).

88. Feng, X.; Li, Q.; Zhu, Y.; Hou, J.; Jin, L.; Wang, J. Artificial neural networks forecasting of PM 2.5 pollution using air mass trajectory based geographic model and wavelet transformation. Atmos. Environ. 2015, 107, 118-128. [CrossRef]

89. Sun, G.; Hoff, S.J.; Zelle, B.C.; Nelson, M.A. Forecasting daily source air quality using multivariate statistical analysis and radial basis function networks. J. Air. Waste Manag. Assoc. 2012, 58, 1571-1578. [CrossRef]

90. Lu, J.; Hu, H.; Bai, Y. Radial basis function neural network based on an improved exponential decreasing inertia weight-particle swarm optimization algorithm for AQI prediction. Abstr. Appl. Anal. 2014, 2014, 1-9. [CrossRef]

91. Abdullah, S.; Ismail, M.; Ghazali, N.A.; Ahmed, A.N. Forecasting particulate matter $\left(\mathrm{PM}_{10}\right)$ concentration: A radial basis function neural network approach. Adv. Civ. Eng. Sci. Technol. 2018, 2020, 020-043. [CrossRef]

92. Jang, J.-S.R. ANFIS: Adaptive network based fuzzy inference system. IEEE Trans. Syst. Man Cybern. 1993, 23, 665-685. [CrossRef]

93. Mihalache, S.F.; Popescu, M.; Oprea, M. Particulate matter prediction using ANFIS modelling. In Proceedings of the 19th International Conference on System Theory, Control and Computing, Cheile Gradistei, Romania, 14-16 October 2015.

94. Oprea, M.; Mihalache, S.F.; Popescu, M. A comparative study of computational intelligence techniques applied to $\mathrm{PM}_{2.5}$ air pollution forecasting. In Proceedings of the 16th International Conference on Computers Communications and Control, Oradea, Romania, 10-14 May 2016; pp. 103-108.

95. Yildirim, Y.; Bayramoglu, M. Adaptive neuro-fuzzy based modelling for prediction of air pollution daily levels in city of zonguldak. Chemosphere 2006, 63, 1575-1582. [CrossRef] [PubMed]

96. Marija, S.; Ivan, M.; Zivan, Z. An ANFIS-based air quality model for prediction of $\mathrm{SO}_{2}$ concentration in urban area. Serb. J. Manag. 2013, 8, 25-38. [CrossRef]

97. Domanska, D.; Wojtylak, M. Application of fuzzy time series models for forecasting pollution concentrations. Expert Syst. Appl. 2012, 39, 7673-7679. [CrossRef]

98. Polat, K.; Durduran, S.S. Usage of output-dependent data scaling in modeling and prediction of air pollution daily concentration values $\left(\mathrm{PM}_{10}\right)$ in the city of Konya. Neural Comput. Appl. 2011, 21, 2153-2162. [CrossRef] 